\title{
PENGARUH PERAN TEKNOLOGI, ORIENTASI PASAR, PELATIHAN, DAN INFRASTRUKTUR TERHADAP KEUNGGULAN BERSAING BANK SYARIAH
}

\section{THE EFFECT OF ROLE OF TECHNOLOGY, MARKET ORIENTATION, TRAINING, AND INFRASTRUCTURE TO THE COMPETITIVE ADVANTAGE OF SHARIA BANKS}

\author{
Himyar Pasrizal \\ Fakultas Ekonomi dan Bisnis Islam IAIN Batusangkar \\ Jl. Sudirman No. 137, Kuburajo, Lima Kaum, Batusangkar \\ e-mail: himyarpasrizal@iainbatusangkar.ac.id
}

Naskah diterima 26 Juli 2019, di-review 27 Agustus 2019, disetujui 13 Desember 2019

\begin{abstract}
Management of the organizational environment becomes an important part for a company in addition to human resource management in order to create competitive advantage. A company must be careful in managing its environment both internal and external environment. Internal environmental factors such as the ability of human resources, financial capabilities, the role of technology, and market orientation. While some of the company's external environmental factors include infrastructure support and training. Changes in the environment are adapted by companies by formulating corporate strategies and creating competitive advantage. Therefore, Islamic banks in the face of competition from financial institutions, especially with conventional banks, must be able to manage the environment professionally. Management of the technological environment, market orientation, and professional training at Islamic banks will be able to increase the competitive advantage of Islamic banks themselves. While the management of infrastructure is not a special concern for Islamic banks because it does not have an impact on competitive advantage.
\end{abstract}

Keywords: The Role of Technology, Market Orientation, Training, Infrastructure Support, Competitive Advantage, Sharia Banks

\begin{abstract}
Abstrak: Pengelolaan lingkungan organisasi menjadi bagian penting bagi sebuah perusahaan di samping manajemen sumber daya manusia dalam rangka menciptakan keunggulan bersaing. Sebuah perusahaan harus cermat dalam melakukan pengelolaan lingkungannya baik lingkungan internal maupun eksternal. Faktor lingkungan internal seperti kemampuan sumber daya manusia, kemampuan keuangan, peran teknologi, dan orientasi pasar. Sedangkan beberapa faktor lingkungan eksternal perusahaan di antaranya adalah dukungan infrastruktur dan pelatihan. Perubahan lingkungan diadaptasi oleh perusahaan dengan melakukan formulasi strategi perusahaan dan menciptakan keunggulan bersaing. Oleh karena itu, bank syariah dalam menghadapi persaingan lembaga keuangan terutama dengan bank-bank konvensional harus mampu mengelola lingkungan secara profesional. Pengelolaan lingkungan teknologi, orientasi pasar, dan pelatihan yang profesional pada bank syariah akan dapat meningkatkan keunggulan bersaing bank syariah itu sendiri. Sedangkan pengelolaan terhadap infrastruktur tidak menjadi perhatian khusus bagi bank syariah karena tidak berdampak terhadap keunggulan bersaing.
\end{abstract}

Kata Kunci: Peran teknologi, Orientasi Pasar, Pelatihan, Infrastruktur, Keunggulan Bersaing, dan Bank Syariah

\section{PENDAHULUAN}

P erubahan lingkungan baik internal maupun eksternal merupakan sumber perubahan kondisi atau keadaan yang menciptakan peluang dan ancaman perusahaan (Kotler, 2000). Perubahan lingkungan diadaptasi oleh perusahaan 
dengan melakukan formulasi strategi perusahaan dan menciptakan keunggulan bersaing sehingga perusahaan dapat terus eksis dalam bisnis. Hal ini juga didukung oleh pernyataan Minztberg (1990) dalam Suryana (2003) bahwa teori "Design School" yaitu perusahaan harus mendesain strategi perusahaan yang cocok antara peluang dan ancaman eksternal dengan kemampuan internal yang memadai dan berpedoman kepada pilihan alternatif dari grand strategy, kemudian didukung dengan menumbuhkan kapabilitas inti (core competency) yang merupakan kompetensi khusus (distinctive competency) dari pengelolaan sumber daya perusahaan.

MenurutKotler (2000) terdapatempat variabel yang harus dipertimbangkan dalam analisis lingkungan internal yaitu pemasaran, keuangan, produksi dan organisasi dalam menentukan strategi untuk menciptakan keunggulan bersaing. Beberapa penelitian yang memperkuat pernyataan tersebutadalah Nurhajati (2003) mengungkapkan bahwa lingkungan internal yaitu sumber daya finansial, sumber daya fisik, sumber daya manusia, sumber daya teknologi dan organisasi berpengaruh signifikan terhadap keunggulan bersaing usaha kecil. Selain itu, implikasi dari pola organisasi dan administrasi yang baik serta keterampilan manajerial menciptakan keunggulan bersaingyang berkelanjutan (Gomez et al, 2007).

Menurut Mahoney dan Pandian (1992) dalam Suryana (2003), untuk menghadapi persaingan yang semakin kompleks dan krisis eksternal, perusahaan dapat menggunakan teori "resource based strategy". Teori ini dinilai potensial untuk memelihara keberhasilan perusahaan dalam keadaan krisis ekonomi yang berkepanjangan di
Indonesia seperti sekarang. Teori ini mensyaratkan adanya transparansi, sukar ditiru atau dialihkan oleh pesaing dan memberi daya saing jangka panjang yang melebihi tuntutan-tuntutan masa kini di pasar dan tahan menghadapi masalah resesi. Faktor produksi sebagai sumber daya organisasi berupa tanah, teknologi, tenaga kerja, modal, dan budaya bisa dimanage untuk memperoleh keuntungan dan keunggulan bersaing.

Untuk meraih keuntungan yang berkesinambungan, perusahaan harus berusaha mencari dan menumbuhkan kapabilitas khusus dari semua sumber daya yang mungkin belum dimanfaatkan secara optimal dan dapat diubah menjadi peluang produktif yang unik, diantaranya melalui pencarian ide-ide baru atau wawasan manajemen yang lebih luas secara terus-menerus. Berdasarkan teori resource based strategy, perusahaan dapat meraih keunggulan melalui penggunaan sumber daya yang lebih baik, yaitu dengan:

1. Pola organisasi dan administrasi yang baik

2. Perpaduan aset fisik yang "tangible" seperti sumber keuangan, sumber daya organisasi, sumber daya fisik, dan teknologi serta aset"intangible" seperti sumber daya manusia, kebiasaan berpikir kreatif dan inovatif, dan reputasi perusahaan (Hitt, et al., 2005).

3. Budaya perusahaan (corporate culture)

4. Proses kerja dan penyesuaian yang segera atas tuntutan baru (time respones compression)

Michael Porter (1980) yang terkenal dengan teori Competitive Strategy, mengemukakan bahwa perusahaan harus menciptakan daya saing khusus agar memiliki posisi tawar menawar 
yang kuat (bargaining power) dalam persaingan. Kompetensi perusahaan diciptakan melalui generic strategies milik Porter (1993), yaitu strategi biaya rendah, diferensiasi dan fokus, serta didukung oleh nilai-nilai budaya yang relevan. Menurut strategi ini, perusahaan harus mencari pasar yang kuat dengan biaya yang rendah yang harus menjadi senjata utama dalam persaingan.

Keunggulan bersaing berkembang dari nilai yang mampu diciptakan oleh perusahaan bagi pelanggan atau pembeli. Keunggulan bersaing menggambarkan cara perusahaan memilih dan mengimplementasikan strategi generik (biaya rendah, diferensiasi, dan fokus) untuk mencapai dan mempertahankan keunggulan bersaing. Dengan kata lain keunggulan bersaing menyangkut bagaimana suatu perusahaan benarbenar menerapkan strategi generiknya dalam kegiatan praktis (Porter, 1980). Bennett \& Smith (2002) mengemukakan pernyataan yang sama bahwa perusahaan kecil manufaktur dan jasa yang berkembang cenderung menggunakan strategi diferensiasi untuk menciptakan keunggulan bersaing.

Berdasarkan realitas yang terjadi bahwa persaingan bisnis saat ini sangatlah dinamis karena perang harga antar perusahaan semakin meningkat sehingga dibutuhkan strategi untuk mempertahankan eksistensi perusahaan (O'Regan dan Ghobadian, 2004). Berbagai hasil studi empirik yang telah dikemukakan di atas menyajikan hasil yang berbeda-beda tentang variabel-variabel yang mempengaruhi keunggulan bersaing suatu perusahaan.

Kartajaya dan Sula (2006), juga mengemukakan mengenai strategi bersaing melalui positioning, bahwa setelah menemukan produk yang sesuai dengan kebutuhan dan keinginan konsumen, perusahaan harus mengetahui posisinya di tengah arena kompetisi. Apakah ada penawaran yang sama dari perusahaan lain? Dengan mengetahui posisi di tengah pemain yang lain, positioning yang ditawarkan bisa berbeda dari pesaing. Positioning ini juga harus bisa sustainable terhadap perubahan-perubahan yang terjadi di pasar. Tetapi, walaupun positioning harus bisa berkelanjutan dan relevan dalam berbagai situasi, positioning harus dikomunikasikan secara konsisten dan tidak berubah-ubah.

Bagi bank syariah, membangun positioning yang kuat dan positif sangatlah penting. Citra syariah dengan sendirinya akan terbentuk, harus bisa dipertahankan dengan menawarkan value-value yang sesuai dengan prinsip syariah. Pemenuhan terhadap prinsip-prinsip syariah merupakan hal generik yang wajib dan harus dijalankan berdasarkan kompetensi yang dimiliki bank syariah. Sehingga, dalam menentukan positioning, perusahaan bisa menampilkan keunggulan komparatif dan kompetitifnya. Kartajaya dan Sula (2006), juga mengemukakan bahwa positioning memegang peranan penting dalam memasarkan produk-produk perusahaan, karena membangun positioning berarti membangun kepercayaan konsumen. Untuk bank syariah, membangun kepercayaan konsumen dapatberarti menunjukkan komitmen bahwa bank syariah itu menawarkan sesuatu yang lebih jika dibandingkan dengan pesaingnya.

Keunggulan bersaing juga dipengaruhi oleh lingkungan eksternal. Hal ini terbukti dalam penelitian Beaver dan Christopher (2002) yang 
mengemukakan bahwa pemerintah dalam hal memberikan kebijakan yang tepat (peraturan pemerintah, sarana dan prasarana, informasi, pendidikan dan pelatihan) dan kondisi perekonomian suatu negara merupakan faktor dalam mendukung eksistensi sebuah perusahaan.

Interaksi dan koordinasi antara institusi pemerintah, organisasi lokal, asosiasi perdagangan dan industri, perusahaan pelatihan dan pengembangan, dan beberapa organisasi yang berhubungan dengan lingkungan eksternal perusahaan berperan penting dalam membantu perusahaan untuk menghadapi persaingan bisnis dan bertahan dalam kondisi bisnis tersebut (Gomez, et al., 2007). Namun, dari hasil penelitian Nurhajati (2003) menyatakan bahwa lingkungan eksternal seperti kebijakan pemerintah dan kemampuan pembeli tidak berpengaruh terhadap keunggulan bersaing. Hal ini sejalan dengan penelitian Bennett \& Colin Smith (2002) bahwa kebijakan pemerintah terbukti tidak berpengaruh signifikan terhadap keunggulan bersaing.

\section{KERANGKA KONSEPTUAL}

\section{Manajemen Strategi}

Proses manajemen strategi pada umumnya terdiri dari empat elemen dasar yaitu pengamatan lingkungan, perumusan strategi, implementasi strategi dan evaluasi dan pengendalian. Penelitian ini menggunakan dua elemen dasar dalam konsep manajemen strategi, yaitu pengamatan lingkungan dan perumusan strategi. Pengamatan lingkungan dilakukan dengan mengamati lingkungan internal dan eksternal. Perumusan strategiyaitumerumuskan strategi berdasarkan strategi generik untuk menciptakan keunggulan bersaing. David (2001) mendefinisikan manajemen strategi adalah suatu proses yang digunakan oleh manajer dan karyawan untuk merumuskan dan mengimplementasikan strategi dalam penyediaan costumer value terbaik untuk mewujudkan visi organisasi.

Berdasarkan definisi beberapa pakar manajemen, maka frasa penting manajemen strategi adalah sebagai berikut:

1. Manajemen strategi merupakan suatu proses.

2. Proses digunakan untuk merumuskan dan mengimplementasikan strategi.

3. Strategi digunakan untuk menyediakan costumer value terbaik.

4. Manajer dan karyawan adalah pelaku manajemen strategi.

\section{Strategi Perusahaan Untuk Keunggulan Bersaing}

Suatu perusahaan dikatakan mempunyai keunggulan bersaing bilamana memiliki sesuatu yang lebih atas pesaingnya dalam menarik konsumen dan mempertahankan diri atas kekuatan persaingan yang mencoba menekan perusahaan. Sumber keunggulan bersaing berupa produk terbaik di pasar, memberikan jasa pelayanan yang paling hebat, memberikan harga jual yang paling murah, punya lokasi yang paling strategis, teknologi yang tepat guna, atribut barang yang sesuai dengan kehendak konsumen, memasarkan produk baru paling cepat, merek dan reputasi yang sudah teruji dan memberikan nilai barangyang lebih besar daripada uangyang dikeluarkan konsumen (Bambang, 2003).

Lima kekuatan persaingan mencerminkan kenyataan bahwa persaingan dalam suatu industri tidak terbatas pada jumlah perusahaan yang ada. 
Pelanggan, pemasok produk pengganti, serta pendatang baru potensial semuanya merupakan pesaing bagi perusahaan-perusahaan dalam industri. Kekuatan persaingan ini secara bersamasama menentukan intensitas persaingan dan kemampuan memperoleh keuntungan dalam industri dan kekuatan-kekuatan yang paling besar akan menentukan, serta menjadi sangat penting dari sudut pandang penentuan strategi.

Dasar keunggulan bersaing yang digabungkan menghasilkan tiga strategi generikyaitu keunggulan biaya, diferensiasi dan fokus. Masing-masing strategi generik melibatkan rute yang berbeda secara fundamental terhadap keunggulan bersaing, yang menggabungkan suatu pilihan mengenai jenis keunggulan bersaing diharapkan tercapai. Strategi keunggulan biaya dan diferensiasi mengusahakan keunggulan bersaing dalam jajaran luas segmen industri, sementara strategi fokus ditujukan pada keunggulan biaya atau diferensiasi dalam segmen yang sempit.

Konsep strategi generik menekankan bahwa keunggulan bersaing adalah jantung dari setiap strategi dan pencapaian keunggulan bersaing menghendaki suatu perusahaan untuk membuat pilihan, jika perusahaan ingin mencapai keunggulan bersaing, maka perusahaan harus memilih tipe keunggulan bersaing yang diinginkan dan lingkup atau bidang yang ingin dicapai tersebut. Memilih semua tipe akan berakibat kinerja perusahaan berada di bawah rata-rata industri, yang berarti perusahaan tersebut tidak mempunyai keunggulan bersaing.

Industriyang semakin kompetitif menyebabkan semakin berkembangnya strategi generik. Menurut
Strickland (1998), strategi generik dibedakan menjadi lima kelompok yaitu:

1. A low-cost strategy yaitu strategi bersaing berdasarkan konsumen dengan menekan biaya untuk menghasilkan produk atau jasa.

2. A broad differentiation strategy yaitu strategi bersaing dengan memberikan diferensiasi produk atau jasa yang berbeda dari pesaingnya.

3. A best-cost provider yaitu strategi bersaing dengan memberikan nilai lebih terhadap produk atau jasa melalui penekanan biaya dan meningkatkan diferensiasi sehingga konsumen merasa mendapatkan tambahan nilai atas produk atau jasa yang dibayarkan melalui uang.

4. A focused or market niche strategy based on lower cost yaitu strategi bersaing dengan menekan biaya produksi dan berkonsentrasi terhadap segmen konsumen tertentu.

5. A focused or market niche strategy based on differentiation yaitu strategi bersaing dengan diferensiasi produkatau jasa dan berkonsentrasi terhadap segmen konsumen tertentu.

Strategi generik Strickland (1998) merupakan pengembangan dari strategi generik Porter (1980). Penambahan strategi yang dikemukakan Strickland (1998) adalah strategi a best-cost provider. Dalam strategi ini konsumen diberikan nilai tambah atas uang yang telah dibayarkan. Strategi a best-cost provider merupakan kombinasi antara strategi kepemimpinan biaya dan diferensiasi. Pada strategi ini biaya diminimumkan namun produk atau jasa yang dihasilkan mempunyai kualitas, penampilan dan performa yang tinggi dan berbeda dari pesaingnya. Ide dari strategi ini adalah menciptakan nilai tinggi produk 
atau jasa sesuai dengan harapan pembeli melalui kunci kualitas, layanan, penampilan dan performa namun dengan harga yang kompetitif.

\section{Analisis Lingkungan Internal}

Pokok perumusan strategi bersaing adalah menghubungkan perusahaan dengan lingkungannya (Porter, 1980). Walaupun lingkungan yang relevan sangat luas, meliputi kekuatan-kekuatan sosial sebagaimana juga kekuatan-kekuatan ekonomi, aspek utama dari lingkungan perusahaan adalah industri dimana perusahaan tersebut bersaing. Struktur industri mempunyai pengaruh yang kuat dalam menentukan aturan permainan persaingan selain juga strategi-strategi yang secara potensial tersedia bagi perusahaan. Kekuatan-kekuatan di luar industri penting karena kekuatan luar biasanya mempengaruhi semua perusahaan yang ada dalam suatu industri, maka kuncinya terletak pada kemampuan perusahaan dalam lingkungan bersaing untuk menanggulanginya.

Melalui analisis lingkungan internal, perusahaan menentukan apa yang dapat dilakukannya, yaitu tindakan yang dimungkinkan oleh sumber daya, kemampuan dan kompetisi inti yang dimiliki. Pencocokan antara apa yang dapat dilakukan perusahaan dengan apa yang mungkin dilakukan, memungkinkan pengembangan strategic intent dan strategic mission serta pemilihan strategi pencipta nilai.

Menurut Kotler (2000) terdapat empat faktor yang harus dipertimbangkan dalam analisis lingkungan internal, yaitu:

1. Pemasaran, yang terdiri dari variabel: Reputasi perusahaan, Pangsa pasar, Kepuasan konsumen, Customer retention, Kualitas pelayanan, Efektifitas penetapan harga, Efektifitas distribusi, Efektifitas promosi, Efektifitas tenaga penjualan, Efektifitas inovasi, Daya jangkau geografis.

2. Keuangan, yang terdiri dari variabel: Biaya atau tersedianya modal, Cash flow/arus uang tunai, dan Stabilitas keuangan.

3. Produksi, yang terdiri dari variabel: Fasilitas, Skala ekonomis, Kapasitas, Karyawan yang mampu dan setia, Ketepatan waktu dalam berproduksi, dan Ketrampilan teknik produksi.

4. Organisasi, yang terdiri dari: Kepemimpinan yang mampu dan berpandangan kedepan, Para pegawai yang setia, Orientasi kewirausahaan, dan Fleksibilitas/kemampuan beradaptasi.

\section{Analisis Lingkungan Eksternal}

Lingkungan eksternal perusahaan perlu dianalisis dalam rangka membuat formulasi strategi perusahaan. Beberapa variabel yang perlu dianalisis pada lingkungan eksternal dikenal sebagai peluang dan ancaman (opportunity and threath). Wheelen dan Hunger (2004), mengemukakan bahwa lingkungan eksternal suatu perusahaan terdiri dari dua kelompok faktor yang saling terkait satu sama lainnya yang berperan penting dalam penentuan peluang, tantangan, dan ancaman bagi perusahaan. Faktor pertama dikenal sebagai societal environment yang merupakan variabel-variabel eksternal berasal dari luar dan biasanya tidak memandang situasi operasional sebuah perusahaan. Variabel tersebut adalah variabel ekonomi, sosial, budaya, politik, teknologi. Faktor kedua adalah 
industry environment yang di antaranya adalah pemerintah, pemasok, pesaing, dan konsumen.

Menurut David (2003) membagi lingkungan eksternal atas tiga kategori:

1. Lingkungan Umum

a. Faktor perekonomian yaitu kondisi perekonomian negara pada waktu sekarang dan dimasa yang akan datang dapat mempengaruhi keberuntungan dan strategi perusahaan.

b. Faktor sosial yaitu nilai dan sikap pelanggan dan karyawan yang dapat mempengaruhi strategi. Nilai-nilai ini mewujud ke dalam perubahan gaya hidup yang mempengaruhi permintaan terhadap produk dan jasa ataupun cara perusahaan berhubungan dengan karyawannya.

c. Faktor teknologi mencakup tidak hanya pada segi produk yang dihasilkan tetapi lebih luas pada seluruh lini perusahaan, seperti bahan baku, kualitas sumber daya manusia dan kegiatan produksi. Modernisasi teknologi secara langsung maupun tidak langsung dapat mempengaruhi penetapan strategi yang akan dijalankan.

d. Faktor pemerintah yaitu berhubungan dengan hukum dan peraturan seperti pengendalian gaji dan harga, peluang kerja sama, keamanan dan kesehatan di tempat kerja, cara pengurusan kredit nasabah, lokasi pembangunan pabrik, cara pemasangan iklan.
2. Lingkungan Industri

a. Faktor pelanggan yaitu perusahaan lebih menaruh perhatian pada jenis konsumen serta kebutuhan dan keinginan konsumen.

b. Faktor pemasokyaitu memberikan modal, tenaga kerja, bahan dan sebagainya kepada perusahaan.

c. Faktor pesaing yaitu meneliti keadaan pasar yang harus dihadapi perusahaan dalam hubungannya dengan pesaing yaitu masuknya dan keluarnya pesaing utama, ketersediaan produk dan jasa pengganti, perubahan penting dalam strategi pesaing yang sekarang.

3. Lingkungan Internasional

Lingkungan internasional meliputi semua faktor diatas tetapi sifat ancaman dan peluang mengambil fokus yang berbeda. Lingkungan internasional lebih bersifatbersaing, heterogen, dan rumitkarena adanya perbedaan masyarakat dan budaya, praktek pendidikan, struktur hukum, politik, ekonomi dan ideologi mengenai praktek bisnis yang layak.

\section{Hipotesis Penelitian}

Hipotesis yang diajukan dalam penelitian ini adalah berdasarkan kepada kajian riset sebelumnya dan kajian teori yang telah diuraikan di atas. Maka hipotesis tersebut adalah sebagai berikut:

1. Peran teknologi dan orientasi pasar berpengaruh secara signifikan terhadap keunggulan bersaing bank syariah.

2. Dukungan infrastruktur dan pelatihan berpengaruh secara signifikan terhadap keunggulan bersaing bank syariah. 


\section{METODE PENELTIIAN}

\section{Jenis Penelitian}

Jenis penelitian ini adalah penelitian terapan (applied research). Penelitian terapan adalah penelitian yang bertujuan untuk memecahkan masalah manajemen (Ferdinand Augusty, 2006). Penelitian ini juga termasuk penelitian hypothesis testing research. Penelitian hypothesis testing research adalah penelitian yang menguji hipotesis. Selain itu, penelitian ini termasuk hypothesis generating research. Penelitian hypothesis generating research adalah penelitian yang menguji secara empirik hipotesis yang dibangun (Ferdinand Augusty, 2006). Secara garis besar, tujuan dari penelitian ini adalah menguji atau membuktikan hipotesis dan untuk membantu peneliti dalam memilih tindakan khusus selanjutnya sehingga dapat dikategorikan jenis penelitian eksplanatori (Singarimbun dan Effendi, 1995).

\section{Populasi dan Sampel}

Populasi dalam penelitian ini adalah seluruh bank syariah yang ada di Propinsi Sumatera Barat. Sedangkan sampel yang diambil adalah bank syariah yang ada di Kota Batusangkar, Bukittinggi, dan Padangpanjang dengan teknik pengambilan sampel adalah purposive sampling.

\section{Jenis dan Sumber Data}

Jenis data yang diperlukan dalam penelitian ini adalah data primer dan sekunder.

1. Data Primer, adalah merupakan data yang diperoleh langsung dari sumber asli di lapangan tanpa mengalami pengolahan terlebih dahulu.

158 | Himyar Pasrizal
2. Data Sekunder, adalah data-data yang sudah mengalami pengolahan terlebih dahulu yang dapat berasal dari dokumen atau catatan perusahaan atau pun media masa dan lembaga lainnya.

\section{Teknik Pengumpulan Data}

Metode pengumpulan data primer dengan menggunakan instrumen berupa daftar pernyataan (Questionaire). Daftar pernyataan berdasarkan indikator-indikator dari variabel laten yaitu lingkungan internal (kemampuan SDM karyawan, sumber daya keuangan, peran teknologi, orientasi pasar); lingkungan eksternal (kemampuan pembeli, informasi, dukungan infrastuktur, pendidikan dan pelatihan). dan variabel dependen yaitu keunggulan bersaing

\section{Instrumen Penelitian}

Dalam penelitian ini dibagikan kuesioner yang disusun dalam kalimat-kalimat pernyataan. Responden diminta memberikan tanggapannya dengan memilih salah satu pilihan jawaban berupa tanda silang pada skor jawaban yang telah disediakan. Jawaban dari responden yang bersifat kualitatif ditransformasikan menjadi kuantitaf dan diukur dengan menggunakan skala Likert. Penentuan skor pada masing-masing item pernyataan terhadap masalah yang diteliti diukur dengan skala Likert lima kategori, yaitu skala yang berhubungan dengan pernyataan sikap seseorang terhadap sesuatu (Cooper, 1996).

\section{Uji Validitas dan Reabilitas}

Setelah data diperoleh, maka dilakukan pengujian data untuk meyakinkan bahwa instrumen yang dipakai dapat difungsikan dengan baik; 


\section{Uji Validitas Instrumen Penelitian}

Uji validitas merujuk kepada sejauh mana suatu uji dapatmengukur apayang sebenarnya ingin kita ukur (Cooper, 1996). Tujuan dari uji validitas adalah untuk mengetahui valid tidaknya instrumen pengukuran. Uji validitas yang dilakukan dalam penelitian ini adalah uji validitas konstruk (construct validity) yaitu dengan menggunakan analisis item melalui perhitungan koefisien korelasi antara skor item dengan skor totalnya dalam taraf signifikansi 5\% menggunakan rumus product moment:

$$
r=\frac{\{N(\Sigma X)\}-\{(\Sigma X)(\Sigma Y)\}}{\left.\left.\sqrt{\left\{\left(N \Sigma X^{2}\right)-(\Sigma X)^{2}\right)}\right\}\left(N \Sigma Y^{2}\right)-(\Sigma Y)^{2}\right\}}
$$

Keterangan :

$\mathrm{N}=$ Jumlah Responden

$\mathrm{X}=$ Skor Total per Item

$\mathrm{Y}=$ Skor Total

Suatu instrumen dapat dikatakan valid jika nilai $r>0,3$. Jadi, apabila korelasi antara skor masing-masing dengan skor total $<0,3$ maka butir dalam instrumen tersebut dinyatakan tidak valid, instrumen dianggap valid jika memenuhi toleransi kesalahan sebesar $\alpha$ $=0,05$ untuk penelitian mengenai perilaku atau sikap (Sugiyono, 2001). Valid tidaknya suatu item instrumen dapat diketahui dengan membandingkan indeks korelasi product moment pearson (Singarimbun dan Effendi, 1995) dengan Level of Significant 5 \% terhadap nilai korelasinya. Bila signifikansi hasil korelasi lebih dari 0,05 maka dinyatakan valid.

\section{Uji Reliabilitas Instrumen Penelitian}

Reliabilitas adalah indeks yang menunjukkan sejauh mana suatu alat ukur dapat dipercaya atau dapat diandalkan. Uji reliabilitas disini akan menggunakan formula koefisien Alpha Cronbach (Damodar Gujarati,1999) dengan rumus :

$r_{\mathbb{1 1}}=\left(\frac{K}{K-1}\right)\left(1-\frac{\Sigma \sigma_{b}^{2}}{\sigma_{t}^{2}}\right)$

Keterangan :

$\mathrm{r}_{11}=$ Reliabilitas Instrumen

$\mathrm{K}$ = Banyaknya butir pernyataan atau banyaknya soal

$\sigma_{b}^{2}=$ Jumlah varians butir pernyataan

$\sigma_{t}^{2}=$ Jumlah total

Jika koefisien Alpha menunjukkan $\geq 0.6$, maka dapat dikatakan bahwa atribut-atribut dalam kuesioner tersebut adalah reliabel untuk digunakan sebagai input dalam proses penganalisaan data (Maholtra,1993).

\section{PEMBAHASAN DAN HASIL}

Sesuai dengan tujuan dari penelitian ini adalah menganalisis pengaruh variabel lingkungan internal dan eksternal terhadap keunggulan bersaing bank syariah berdasarkan strategi generik keunggulan bersaing yang dikemukakan oleh Porter. Maka untuk itu dilakukan uji validitas, uji realibitas, uji asumsi klasik dan analisis regresi.

Tabel 1

Hasil Uji Validitas Instrumen Penelitian

\begin{tabular}{|l|l|l|l|l|}
\hline \multicolumn{1}{|c|}{ Variabel } & \multicolumn{1}{c|}{ Indikator } & \multicolumn{1}{c|}{ Korelasi } & Sig. & Keterangan \\
\hline $\mathrm{X} 1$ & $\mathrm{X} 1.1$ & 0,714 & 0,000 & Valid \\
\hline
\end{tabular}




\begin{tabular}{|l|l|l|l|l|}
\hline & $\mathrm{X} 1.2$ & 0,815 & 0,000 & Valid \\
\hline & $\mathrm{X} 1.3$ & 0,780 & 0,000 & Valid \\
\hline & $\mathrm{X} 1.4$ & 0,786 & 0,000 & Valid \\
\hline $\mathrm{X} 2$ & $\mathrm{X} 2.1$ & 0,841 & 0,000 & Valid \\
\hline & $\mathrm{X} 2.2$ & 0,801 & 0,000 & Valid \\
\hline & $\mathrm{X} 2.3$ & 0,851 & 0,000 & Valid \\
\hline & $\mathrm{X} 2.4$ & 0,880 & 0,000 & Valid \\
\hline & $\mathrm{X} 2.5$ & 0,835 & 0,000 & Valid \\
\hline & $\mathrm{X} 2.6$ & 0,782 & 0,000 & Valid \\
\hline & $\mathrm{X} 2.7$ & 0,827 & 0,000 & Valid \\
\hline $\mathrm{X} 3$ & $\mathrm{X} .1$ & 0,883 & 0,000 & Valid \\
\hline & $\mathrm{X} 3.2$ & 0,906 & 0,000 & Valid \\
\hline $\mathrm{X} 4$ & $\mathrm{X} 4.1$ & 0,870 & 0,000 & Valid \\
\hline & $\mathrm{X} 4.2$ & 0,908 & 0,000 & Valid \\
\hline & $\mathrm{X} 4.3$ & 0,878 & 0,000 & Valid \\
\hline $\mathrm{Y}$ & $\mathrm{Y} 1.1$ & 0,881 & 0,000 & Valid \\
\hline & $\mathrm{Y} 1.2$ & 0,890 & 0,000 & Valid \\
\hline & $\mathrm{Y} 1.3$ & 0,875 & 0,000 & Valid \\
\hline
\end{tabular}

Sumber : Data Primer (diolah)

Hasil uji validitas yang dilakukan dengan menggunakan program SPSS for Windows, dapat dilihat pada Tabel 1. bahwa nilai koefisien korelasi antar skor indikator dengan skor totalnya dari variabel peran tekonologi (X1), orientasi pasar (X2), dukungan infrastruktur (X3), pelatihan (X4), dan keunggulan bersaing $(Y)$ mempunyai nilai korelasiyang lebih besar dari 0.3 dan taraf signifikansi kurang dari 5\%, sehingga dapat dikatakan bahwa semua indikator pertanyaan/ pernyataan dalam penelitian ini adalah valid, sehingga dapat dilanjutkan untuk melakukan analisis faktor.

\section{Uji Reliabilitas}

Untuk mengetahui bahwa instrumen penelitian ini dapat diandalkan dan dipercaya maka dilakukan uji reliabilitas. Sehingga hasil pengukuran penelitian ini akan konsisten dari waktu ke waktu. Uji reliabilitas dengan menggunakan nilai Alpha.

Tabel 2

Hasil Uji Reliabilitas Instrumen Penelitian

\begin{tabular}{|l|l|l|}
\hline \multicolumn{1}{|c|}{ Variabel } & \multicolumn{1}{|c|}{ Koefisien Alpha } & \multicolumn{1}{c|}{ Keterangan } \\
\hline X1 & 0,907 & Reliabel \\
\hline X2 & 0,857 & Reliabel \\
\hline X3 & 0,905 & Reliabel \\
\hline X4 & 0,883 & Reliabel \\
\hline Y & 0,920 & Reliabel \\
\hline
\end{tabular}

Sumber: Data Primer (diolah)

Hasil uji reliabilitas dengan menggunakan bersaing (Y) dapat dinyatakan reliabel dengan program SPSS for Windows. Berdasarkan Tabel koefisien Alpha di atas 0,6 sehingga dapat 2. variabel kemampuan peran teknologi (X1), dilakukan pengujian dengan menggunakan orientasi pasar (X2), dukungan infrastruktur (X3), analisis faktor. pendidikan dan pelatihan (X4), dan keunggulan 


\section{Analisis Statistik Deskriptif}

Analisis deskriptif merupakan suatu analisis yang berusaha menjelaskan karakteristik data tanpa membuat suatu kesimpulan (Singgih Santoso, 2001).
Penelitian ini melakukan analisis deskriptif yang merupakan analisisyang digunakan untuk mengetahui deskripsi dari distribusi frekuensi responden berdasarkan kuisioner yang telah dikumpulkan.

Tabel 3

Frekuensi Jawaban Variabel Peran Teknologi

\begin{tabular}{|c|c|c|c|c|c|c|c|c|c|c|c|}
\hline \multirow[t]{3}{*}{ Indikator } & \multicolumn{10}{|c|}{ Skor Jawaban } & \multirow[t]{3}{*}{ Mean } \\
\hline & \multicolumn{2}{|c|}{1} & \multicolumn{2}{|c|}{2} & \multicolumn{2}{|c|}{3} & \multicolumn{2}{|c|}{4} & \multicolumn{2}{|c|}{5} & \\
\hline & $f$ & $\%$ & $f$ & $\%$ & $f$ & $\%$ & $f$ & $\%$ & $f$ & $\%$ & \\
\hline $\mathrm{X} 1.1$ & 0 & 0 & 0 & 0 & 1 & 10 & 6 & 60 & 3 & 30 & 4.20 \\
\hline $\mathrm{X} 1.2$ & 0 & 0 & 0 & 0 & 1 & 10 & 7 & 70 & 2 & 20 & 4.10 \\
\hline $\mathrm{X} 1.3$ & 0 & 0 & 0 & 0 & 1 & 10 & 6 & 60 & 3 & 30 & 4.20 \\
\hline $\mathrm{X} 1.4$ & 0 & 0 & 0 & 0 & 1 & 10 & 6 & 60 & 3 & 30 & 4.20 \\
\hline Rata-rata Mean & & & & & & & & & & & 4.18 \\
\hline
\end{tabular}

Sumber: Data Primer (diolah)

Tabel. 4

Frekuensi Jawaban Variabel Orientasi Pasar

\begin{tabular}{|c|c|c|c|c|c|c|c|c|c|c|c|}
\hline \multirow[t]{3}{*}{ Indikator } & \multicolumn{10}{|c|}{ Skor Jawaban } & \multirow[t]{3}{*}{ Mean } \\
\hline & \multicolumn{2}{|c|}{1} & \multicolumn{2}{|c|}{2} & \multicolumn{2}{|c|}{3} & \multicolumn{2}{|c|}{4} & \multicolumn{2}{|c|}{5} & \\
\hline & $f$ & $\%$ & $F$ & $\%$ & $f$ & $\%$ & $f$ & $\%$ & $f$ & $\%$ & \\
\hline $\mathrm{X} 2.1$ & 0 & 0 & 0 & 0 & 2 & 20 & 6 & 60 & 2 & 20 & 4.00 \\
\hline $\mathrm{X} 2.2$ & 0 & 0 & 0 & 0 & 1 & 10 & 7 & 70 & 2 & 20 & 4.10 \\
\hline $\mathrm{X} 2.3$ & 0 & 0 & 0 & 0 & 1 & 10 & 6 & 60 & 3 & 30 & 4.20 \\
\hline $\mathrm{X} 2.4$ & 0 & 0 & 0 & 0 & 2 & 20 & 6 & 60 & 2 & 20 & 4.00 \\
\hline $\mathrm{X} 2.5$ & 0 & 0 & 0 & 0 & 3 & 30 & 5 & 50 & 2 & 20 & 3.90 \\
\hline $\mathrm{X} 2.6$ & 0 & 0 & 0 & 0 & 0 & 0 & 6 & 60 & 4 & 40 & 4.40 \\
\hline $\mathrm{X} 2.7$ & 0 & 0 & 0 & 0 & 0 & 0 & 6 & 60 & 4 & 40 & 4.40 \\
\hline \multicolumn{11}{|c|}{ Rata-rata Mean } & 4.15 \\
\hline
\end{tabular}

Sumber: Data diolah

Tabel 5

Frekuensi Jawaban Variabel Dukungan Infrastruktur

\begin{tabular}{|c|c|c|c|c|c|c|c|c|c|c|c|}
\hline \multirow[t]{3}{*}{ Indikator } & \multicolumn{10}{|c|}{ Skor Jawaban } & \multirow[t]{3}{*}{ Mean } \\
\hline & \multicolumn{2}{|c|}{1} & \multicolumn{2}{|c|}{2} & \multicolumn{2}{|c|}{3} & \multicolumn{2}{|c|}{4} & \multicolumn{2}{|r|}{5} & \\
\hline & $f$ & $\%$ & $\mathbf{F}$ & $\%$ & $f$ & $\%$ & $\mathbf{f}$ & $\%$ & $\mathbf{f}$ & $\%$ & \\
\hline X3.1 & 0 & 0 & 0 & 0 & 1 & 10 & 6 & 60 & 3 & 30 & 4.20 \\
\hline X3.2 & 0 & 0 & 0 & 0 & 2 & 20 & 6 & 60 & 2 & 20 & 4.00 \\
\hline \multicolumn{11}{|c|}{ Rata-rata Mean } & 4.10 \\
\hline
\end{tabular}

Sumber: Data Primer (diolah)

Tabel 6

Frekuensi Jawaban Variabel Pendidikan dan Pelatihan

\begin{tabular}{|c|c|c|c|c|c|c|c|c|c|c|c|}
\hline \multirow[t]{3}{*}{ Indikator } & \multicolumn{10}{|c|}{ Skor Jawaban } & \multirow[t]{3}{*}{ Mean } \\
\hline & \multicolumn{2}{|c|}{1} & \multicolumn{2}{|c|}{2} & \multicolumn{2}{|c|}{3} & \multicolumn{2}{|c|}{4} & \multicolumn{2}{|c|}{5} & \\
\hline & $f$ & $\%$ & $\mathbf{F}$ & $\%$ & $f$ & $\%$ & $f$ & $\%$ & $f$ & $\%$ & \\
\hline$X 4.1$ & 0 & 0 & 0 & 0 & 2 & 20 & 6 & 60 & 2 & 20 & 4.00 \\
\hline$X 4.2$ & 0 & 0 & 0 & 0 & 3 & 30 & 5 & 50 & 2 & 20 & 3.90 \\
\hline$\times 4.3$ & 0 & 0 & 0 & 0 & 0 & 0 & 6 & 60 & 4 & 40 & 4.40 \\
\hline \multicolumn{11}{|c|}{ Rata-rata Mean } & 4.10 \\
\hline
\end{tabular}

Sumber: Data Primer (diolah)

Pengaruh Peran Teknologi, Orientasi Pasar, Pelatihan, dan Infrastruktur... | 161 
Tabel 7

Frekuensi Jawaban Variabel Keunggulan Bersaing

\begin{tabular}{|c|c|c|c|c|c|c|c|c|c|c|c|}
\hline \multirow[t]{3}{*}{ Indikator } & \multicolumn{10}{|c|}{ Skor Jawaban } & \multirow[t]{3}{*}{ Mean } \\
\hline & \multicolumn{2}{|c|}{1} & \multicolumn{2}{|c|}{2} & \multicolumn{2}{|c|}{3} & \multicolumn{2}{|c|}{4} & \multicolumn{2}{|c|}{5} & \\
\hline & $\mathbf{F}$ & $\%$ & $\mathbf{F}$ & $\%$ & $f$ & $\%$ & $f$ & $\%$ & f & $\%$ & \\
\hline Y1.1 & 0 & 0 & 0 & 0 & 3 & 30 & 5 & 50 & 2 & 20 & 3.90 \\
\hline $\mathrm{Y} 1.2$ & 0 & 0 & 0 & 0 & 0 & 0 & 6 & 60 & 4 & 40 & 4.40 \\
\hline $\mathrm{Y} 1.3$ & 0 & 0 & 0 & 0 & 0 & 0 & 6 & 60 & 4 & 40 & 4.40 \\
\hline Rata-rata Mean & & & & & & & & & & & 4.23 \\
\hline
\end{tabular}

Sumber: Data Diolah

\section{Pengujian Asumsi Klasik}

\section{Uji Normalitas}

Untuk menguji apakah sampel penelitian pengujian Kolmogorov-Smirnov Goodness of Fit Test terhadap masing-masing variabel. Nilai K-S Z dapat dilihat pada tabel 8 berikut.

merupakan jenis distribusi normal maka digunakan

Tabel 8

Uji Normalitas Distribusi

\begin{tabular}{|l|l|l|}
\hline \multicolumn{1}{|c|}{ Variabel } & \multicolumn{1}{c|}{ K-S Z } & \multicolumn{1}{c|}{ Sig } \\
\hline $\begin{array}{l}\text { Peran Teknologi, Orientasi Pasar, Dukungan Infrastuktur, } \\
\text { Pendidikan Dan Pelatihan, dan Keunggulan Bersaing }\end{array}$ & 0.506 & 0.952 \\
\hline
\end{tabular}

Sumber: data diolah

Keterangan: K-S Z: Kolmogorov-Smirnov test Z

Berdasarkan Tabel 8, nilai dari KolmogorovSmirnov test $Z<1,3$ dan signifikansi di atas 5\%. Hal ini menunjukkan bahwa distribusi data merupakan distribusi yang normal sehingga bisa dilakukan analisis regresi linear berganda.

\section{Uji Multikolinearitas}

Model regresi yang bebas dari masalah multikolinearitas adalah dilihat dari Value Inflation Factor (VIF), (Imam Ghozali, 2002). Apabila nilai VIF $>10$ maka terjadi multikolinearitas dan sebaliknya apabila VIF $<10$ maka tidak terjadi multikolinearitas.

Tabel 9

Uji Multikolinearitas, Value Inflation Factor

\begin{tabular}{|l|l|l|}
\hline \multicolumn{1}{|c|}{ Variabel Independen } & \multicolumn{1}{c|}{ Tolerance } & \multicolumn{1}{c|}{ Nilai VIF } \\
\hline Peran Teknologi (X1) & 0.53 & 1.78 \\
\hline Orientasi Pasar (X2) & 0.57 & 1.75 \\
\hline Dukungan Infrastruktur (X3) & 0.54 & 1.62 \\
\hline Pendidikan dan Pelatihan (X4) & 0.62 & 1.89 \\
\hline
\end{tabular}

Sumber: Data diolah

Hasil uji multikolinearitas seperti pada Tabel 9, bahwa nilai tolerance dari masingmasing variabel menunjukkan tidak ada variabel independen yang memiliki nilai tolerance kurang dari 0.10. Hal ini berarti bahwa tidak ada korelasi antar variabel independen yang nilainya sama dengan 1 . Hasil perhitungan nilai VIF juga menunjukkan hal yang sama, tidak ada 
variabel independen yang memiliki nilai VIF lebih dari 10 sehingga dapat dikatakan tidak terjadi masalah multikolinearitas pada model regresi yang digunakan.

\section{Analisis Regresi Linear Berganda}

Dalam pengolahan data dengan menggunakan regresi linear, dilakukan beberapa tahapan untuk mencari hubungan antara variabel independen dan variabel dependen, melalui hubungan variabel lingkungan internal (peran teknologi, orientasi pasar), dan lingkungan eksternal (dukungan infrastuktur, pendidikan dan pelatihan), dengan keunggulan bersaing (Y). Hasil dari analisis regresi menunjukkan bahwa nilai $\mathrm{R}^{2}$ sebesar 0.757 berarti bahwa variabel untuk lingkungan internal (peran teknologi, orientasi pasar), dan lingkungan eksternal (dukungan infrastuktur, pendidikan dan pelatihan), mampu menjelaskan variabel keunggulan bersaing sebesar 75.7\%. Hal ini mengindikasikan variabel-variabel bebas tersebut berperan besar dalam menjelaskan variabel keunggulan bersaing dalam kegiatan usaha perbankan syariah. Pengaruh variabel lain terhadap keunggulan bersaing hanya sebesar $24.3 \%$.

\section{Pengujian Hipotesis}

\section{Pengaruh Peran Teknologi dan Orientasi Pasar terhadap Keunggulan Bersaing}

Untuk menguji bahwa variabel bebas berpengaruh secara parsial terhadap keunggulan bersaing, maka digunakan uji t. Untuk menjawab pengaruh variabel dari lingkungan internal secara parsial yaitu variabel peran teknologi (X1), orientasi pasar (X2) terhadap keunggulan bersaing berdasarkan strategi generik dapat dilihat dari analisis uji t pada Tabel 10.

Tabel 10

Nilai t ${ }_{\text {Hitung }}$ dan Signifikansi Variabel Internal

\begin{tabular}{|l|l|l|l|}
\hline \multicolumn{1}{|c|}{ Variabel Internal } & \multicolumn{1}{c|}{$\mathbf{t}_{\text {hitung }}$} & \multicolumn{1}{c|}{ Sig. } & \multicolumn{1}{c|}{ Keterangan } \\
\hline Peran teknologi (X1) & 2.236 & 0.017 & Signifikan \\
\hline Orientasi pasar (X2) & 2.146 & 0.015 & Signifikan \\
\hline
\end{tabular}

Sumber: Data Diolah

Dari Tabel 10. diketahui bahwa variabel internal peran teknologi berpengaruh signifikan dengan nilai signifikansi 0.017. Dan variabel orientasi pasar juga berpengaruh signifikan terhadap keunggulan bersaing dengan nilai signifikansi sebesar 0.015 .

\section{Pengaruh Dukungan Infrastruktur dan Pelatihan terhadap Keunggulan Bersaing}

Pengaruh variabel lingkungan eksternal, yaitu dukungan infrastruktur (X3), pelatihan (X4) secara parsial terhadap keunggulan bersaing berdasarkan strategi generik. Nilai t-hitung dan signifikansi dapat dilihat pada tabel 11.

Tabel 11

Nilai t- ${ }_{\text {Hitung }}$ dan Signifikansi Variabel Eksternal

\begin{tabular}{|l|l|l|l|}
\hline \multicolumn{1}{|c|}{ Variabel Internal } & \multicolumn{1}{c|}{$\mathbf{t}_{\text {hitung }}$} & \multicolumn{1}{c|}{ Sig. } & \multicolumn{1}{c|}{ Keterangan } \\
\hline Dukungan infrastruktur (X3) & -1.541 & 0.135 & Tidak Signifikan \\
\hline Pelatihan (X4) & 1.987 & 0.049 & Signifikan \\
\hline
\end{tabular}




\section{PEMBAHASAN}

Hasil dari analisis deskriptif menunjukkan bahwas indikator yang paling berkontribusi membentuk variabel keunggulan bersaing berdasarkan strategi generik adalah menciptakan dan memperkenalkan produk yang berbeda dari pesaing dengan memberikan nilai lebih, berkualitas dan diminati masyarakat. Jadi, produk dan jasa bank syariah yang akan dilauncing harus terlebih dahulu melihat apa keinginan, kebutuhan, dan selera masyarakat. Realitas di lapangan menunjukkan bahwa menciptakan dan memperkenalkan produk dan jasa baru belum dilakukan secara baik oleh semua bank syariah. Secara umum, manajemen bank syariah masih menggunakan strategi yang diadopsi dari strategi bank konvensional.

Kajian teori dan kajian riset sebelumnya mengemukakan bahwa lingkungan internal dan lingkungan eksternal berpengaruh dalam menciptakan keunggulan bersaing perusahaan di berbagai bidang industri. Hal ini juga sesuai dengan hasil penelitian. Hasil penelitian memperlihatkan bahwa variabel yang berpengaruh positif terhadap keunggulan bersaing adalah peran teknologi, orientasi pasar, serta pendidikan dan pelatihan. Variabel yang tidak berpengaruh terhadap keunggulan bersaing adalah dukungan infrastruktur.

Penerapan strategi diferensiasi untuk menciptakan keunggulan bersaing dapat terwujud dari bank syariah yang selalu berinovasi. Berdasarkan analisis regresi, variabel yang dominan berperan menciptakan keunggulan bersaing adalah peran teknologi. Artinya bagaimana teknologi dapat mempercepat pengembangan produk baru yang berbeda dan bermutu dalam persaingan. Berdasarkan analisis deskriptif, indikator yang berperan untuk menciptakan peran teknologi adalah pihak bank syariah menggunakan kemajuan teknologi untuk memberikan banyak alternatif kemudahan bertransaksi bagi nasabah. Semakin banyak cara yang bisa ditempuh nasabah semakin memudahkan dan meningkatkan kepuasan nasabah sehingga menciptakan keunggulan tersendiri bagi bank syariah. Bank syariah yang unggul dalam teknologi menciptakan produk dan jasa yang lebih dekat dengan kebutuhan dan keinginan pelanggan, sehingga setiap apa yang diingini oleh nasabah dan masyarakat dapat diakomodir oleh bank.

Untuk menentukan kebijakan-kebijakan yang diambil oleh manajemen bank syariah, salah satu elemen yang dijadikan bahan pertimbangan adalah orientasi pasar. Hasil dari analisis regresi, orientasi pasar berpengaruh positif terhadap keunggulan bersaing. Hal terpenting dalam memenangkan persaingan pada perbankan adalah menciptakan hubungan yang baik dengan konsumen dan memahami serta memenuhi apa yang dibutuhkan oleh konsumen. Bagi beberapa pengusaha, menjaga hubungan baik dengan konsumen berarti dapat memahami apa yang diinginkan oleh pasar. Selain itu, berkomunikasi dengan baik kepada konsumen dapat memberikan informasi tertentu yang dianggap penting untuk kemajuan bisnis.

Untuk dapat menciptakan jenis produk bank yang sesuai dengan permintaan nasabah dan mengetahui kondisi industri perbankan syariah, manajemen bank syariah harus dapat menggali informasi melalui pameran perbankan, majalah, survey produk, dan menjalin kerjasama dengan 
perusahaan lain. Informasi-informasi penting yang harus digali adalah informasi jenis produk dan jasa yang dibutuhkan masyarakat dan belum terakomodir, produk baru dan trend di pasar, dan standard harga serta perkembangan perbankan.

Variabel lingkungan eksternal yang berpengaruh positif terhadap keunggulan bersaing adalah pelatihan. Peran pemerintah untuk memajukan industri perbankan syariah adalah dengan meningkatkan kualitas sumber daya manusia melalui program pelatihan yang dibiayai oleh pemerintah. Hasil analisis bahwa pelatihan tidak hanya dilakukan oleh pemerintah tapi lebih banyak dilakukan oleh pihak bank syariah sendiri. Pelatihan yang dilakukan dapat meningkatkan kemampuan dan keahlian sumber daya manusia dalam peningkatan pelayanan dan mengakomodir kebutuhan dan keinginan nasabah.

Hasil penelitian yang diperoleh cukup unik karena terdapat variabel yang tidak berpengaruh terhadap keunggulan bersaing. Salah satu variabel lingkungan eksternal yang tidak berpengaruh terhadap keunggulan bersaing yaitu dukungan infrastruktur. Sedangkan beberapa variabel dalam penelitian ini tidak dapat diteliti karena keterbatasan waktu dan biaya. Sehingga dapat menjadi celah atau peluang untuk dilakukan penelitian selanjutnya.

Dukungan infrastruktur yaitu dukungan pemerintah dalam memajukan industri perbankan syariah. Pemerintah membangun sarana dan prasarana yang dapat digunakan oleh industri perbankan untuk memperlancar kegiatan dan operasionalisasi bank. Namun, hasil dari analisis regresi, dukungan infrastruktur tidak mempengaruhi keunggulan bersaing bank syariah. Hal ini disebabkan bank syariah juga giat dalam memperkuat strategi promosi dan saluran distribusi, sehingga manajemen bank syariah membangun infrastruktur dengan baik.

\section{PENUTUP}

\section{Kesimpulan}

Dari uraian di atas maka dapat dibuat kesimpulan sebagai berikut:

1. Industri perbankan syariah menghadapi persaingan yang sangat kompetitif terutama dengan perbankan konvensional. Untuk itu perlu manajemen yang baik dan profesional terhadap analisis lingkungan internal dan eksternal.

2. Peran teknologi dan orientasi pasar memberikan pengaruh yang signifikan dalam menciptakan keunggulan bersaing bagi bank syariah. Variabel peran teknologi dan orientasi pasar memberikan pengaruh positif terhadap keunggulan bersaing.

3. Dukungan infrastruktur tidak memberikan pengaruh signifikan terhadap keunggulan bersaing perbankan syariah. Hal ini disebabkan karena bank syariah giat dalam memperkuat strategi promosi dan distribusi. Sedangkan variabel pelatihan memberikan pengaruh signifikan positif terhadap keunggulan bersaing bank syariah.

\section{Saran}

1. Pihak bank syariah seharusnya memberikan perhatian besar terhadap kamajuan teknologi karena teknologi yang unggul akan menjadikan 
produk bank syariah bermutu tinggi dan banyak ragam perbedaan dengan pesaing.

2. Bagi penelitian selanjutnya diharapkan mengambil celah penelitian ini terhadap variabel-variabel yang belum diteliti.

\section{DAFTAR KEPUSTAKAAN}

Augusty Ferdinand. 2006. Metode Penelitian Manajemen, Pedoman Penelitian Untuk Penulisan Skripsi, Tesis dan Disertasi IImu Manajemen.

Cooper, Donald R. dan Emory C. William. 1995. Business Research Methods. Fifth Edition. Richard D. Irwin, Inc. Ellen Gunawan (penterjemah). 1996. Metode Penelitian Bisnis. Edisi Kelima. Jilid 1. Erlangga, Jakarta.

Gomez, Julieta O. Mike Simpson, S.C. Lenny Koh, dan Jo Padmore. 2007. Achieving Competitive Advantage In The Mexican Footware Industry.
Benchmarking : An International Journal Vol. 14:3. Emerald Group Publishing Limited. pp. 289-305.

Maholtra, N.K. 1993. Marketing Research An Applied Orientation. Prentice-Hall International, Inc. London.

Porter, M. E. 1980. Competitive Strategy. Macmillan Publishing Co. Inc. (editor). Agus Maulana (penterjemah).1996. Strategi Bersaing. Teknik Menganalisis Industri dan Pesaing. Penerbit Erlangga, Jakarta.

Singarimbun, Masri dan Sofian Effendi (Editor). 1995. Metode Penelitian Survai. LP3ES, Jakarta.

Singgih Santoso. 2001. SPSS. Statistik Multivariat. Jakarta : Penerbit PT Elex Media Komputindo. Kelompok Gramedia.

Sugiyono. 2001. Metode Penelitian Administrasi. CV Alfabeta, Bandung. 